\title{
Performance Management System in Action, Survey and Questionnaire Finding in Higher Education in Bahrain
}

\author{
Mahmood Asad $^{1} \&$ Joma Mahfod $^{1}$ \\ 1 Department of Management and Marketing, College of Business Administration, University of Bahrain, \\ Kingdom of Bahrain
}

Correspondence: Mahmood Asad, Department of Management and Marketing, College of Business Administration, University of Bahrain, P.O. Box 32038, Kingdom of Bahrain. Tel: 973-1743-8525. E-mail: mamali@uob.edu.bh

Received: May 4, 2015

Accepted: July 3, 2015

Online Published: July 22, 2015

doi:10.5539/ijbm.v10n8p96

URL: http://dx.doi.org/10.5539/ijbm.v10n8p96

\begin{abstract}
This paper focus on performance management system in practice based on survey and questionnaires and supported by literature work. Ever since the establishments of these higher education institutions, little has been done regarding administrative rules and policies on the use of performance management system and practices. Thus, it became compulsory to assess the current system and consider performance management system as one of the important parts. This entails enhancement of the existing performance management system in the above-mentioned selected higher education institutions. The performance management system is expected to standardize the correct method in the system of promotion, and give incentives and rewards to administrative officers and employees in the higher education institutions on a yearly basis. Thus, this research study was conducted to determine the level of adequacy of the present performance management system as a basis of promotion and rewards in the five selected higher education institutions in Bahrain.
\end{abstract}

This study aims to conduct a performance management system audit of selected higher education institutions in Bahrain towards a strategic performance management system.

Specifically, the study addresses the following: What is the profile of these selected five higher education institutions operating in Bahrain's performance management system in the areas of: Demographic profile; Vision, mission, value and strategy; Organization and structure; Employees, talent management, leadership development; Employee relations; Staffing; Continues education program; and Performance management? To what extent do respondents correlate significantly in their perceptions? What are the strengths and weaknesses resulting from the respondents perceptions on the PMS profiles? Based on the findings, what strategic PMS is applicable to the selected higher education institutions? The study aimed to audit the Performance Management System of Higher Education Institutions in the Kingdom of Bahrain towards a strategic performance management system. The descriptive method of research was used in this study with prepared structured questionnaires as basis for the data needed in auditing the present appraisal tool used by higher education institutions. Two groups of respondents namely the administrative managers and administrative employees with the corresponding numbers of 150 each or a total of 300 were the respondents in this study. The study was conducted in the selected five public and private higher education institutions in the Kingdom of Bahrain. These selected higher education institutions are established, one of them a government and a prime institution of higher learning. This primer university was established in the late sixties during the integration of the Higher Education Institutes for male and female teachers into the system. These institutes later integrated with other colleges and formed into the primer government university. The other four higher education institutions were established in the late 1990s and 2000s and maintain their higher learning standards within the requirements of the Ministry of Education in Bahrain. This research environment was based on the current locations of these selected five higher education institutions within Manama and the neighboring towns in the state nation of Bahrain where most of the employees are diversified from the academic staff to administrative employees like Bahrainis, Indians, Pakistanis, Egyptians, western people, other Asian and Arab nationalities among others. Such diversities of people working in these selected higher education institutions made it unique to this study since all of these people are affected for whatever result the performance management system will provide to them. The demographic profile comprised age groups between 31 to 35 ; the respondents' educational attainments; work experiences from 6 to 10 years, and number of years in their present 
jobs. The major areas studied were: Vision, Mission, Value and Strategy; Organization and structure; Employees' talent management, and leadership development; Employee relations; Staffing, Continuous education program; and Performance management. The respondents received copies of the survey questionnaire through e-mail, postal system, or personal approach. The output of the research work served as a basis to derive a strategic performance management system model for higher education institutions in the Kingdom of Bahrain. Responses to the questions were tested at $\alpha=.05$ or $\alpha=.01$ where appropriate. Correlation analysis was used to test significance of associations of respondents' responses. The weighted means were tested for significance using a t-test. To conform with international standards, only means that were at least 3.5 were accepted as strengths and means below 3.5 were considered weaknesses. The Statistical Package for Social Sciences (SPSS) software is used throughout the study to process the data.

Keywords: performance management system, instruments, practices and survey findings

\section{Introduction}

This article concentrates on the performance management system in all levels of management with emphasizes on the top and middle level managers, lower level managers, and rank-and-file employees. The top and middle level managers, which are comprised of all the directors, heads of departments, specialists, and supervisors, are the beneficiaries of this study because it gives them insights in highlighting the needs of this particular level and how the system can help them evaluate and improve their subordinates.

The lower level employees can identify the factors that will help them enhance their skills and qualifications for them to know the mechanics in getting promotions and rewards on a yearly basis. This can inspire them to move forward with the university in their career development plan. In general, it can help evaluate all aspects affecting all levels of employees regardless of their positions in the organization.

\section{Literature Review}

\subsection{Performance Management System}

Performance management system need not be formal in order to be effective. The most important concern in designing a performance management system is its fit with the organization's strategic objectives. Furthermore, the most important concern in providing performance-related feedback is its fit with the organization's culture. There are some companies that decided to do away with formal performance feedback entirely. Instead they opted for a system that provides continuous dialogue on performance-related matters. Executives report that the system works well because it is built on the values of open communication, trust, and self-motivation of employees to do their best. Moreover, any performance-related issues are dealt with in a timely manner because the lack of formality in the process allows feedback to be provided on an ongoing basis (Mello, 2006).

Performance appraisal serves a number of purposes for organizations. According to Robbins (2005), performance appraisal is used by management for general human resource decisions. It provides input into important decisions such as promotions, transfers, terminations, rewards, etc. Through an effective performance appraisal system, employee skills and competencies, as well as needs and inadequacies, can be identified and such can be used as a basis in designing training and development programs. It can also be used as a criterion against the validation of selection and development programs. It also fulfills the purpose of providing feedback to employees on how the organization views their performance. Further, performance appraisal is used as the basis for reward allocations. Decisions as to who gets merit pay increases and other rewards are frequently determined by performance appraisal.

In the educational setting, performance appraisal is used for the same purposes as stated by Robbins (2005). In most cases, promotion to higher academic ranks with corresponding pay increases and other rewards, especially in higher education institutions, is based on performance appraisal. Thus, it is essential to note that there are higher education institutions now operating in the Kingdom of Bahrain develop an effective and adequate performance appraisal system for specific administrative purposes, particularly, as a basis for giving promotions and rewards to their administrative and academic staff.

Ever since the establishments of these higher education institutions, little has been done regarding administrative rules and policies on the use of performance management system and practices. Thus, it became compulsory to assess the current system and consider performance management system as one of the important parts. The performance management system is expected to standardize the correct method in the system of promotion, and give incentives and rewards to administrative officers and employees in the higher education institutions on a yearly basis. Thus, this research study was conducted to determine the level of adequacy of the present performance management system as a basis of promotion and rewards in the five selected higher education 
institutions in Bahrain.

\subsection{Conceptual Framework}

Mello (2006) presents a concept on five strategic decisions as shown in Figure 1. below:

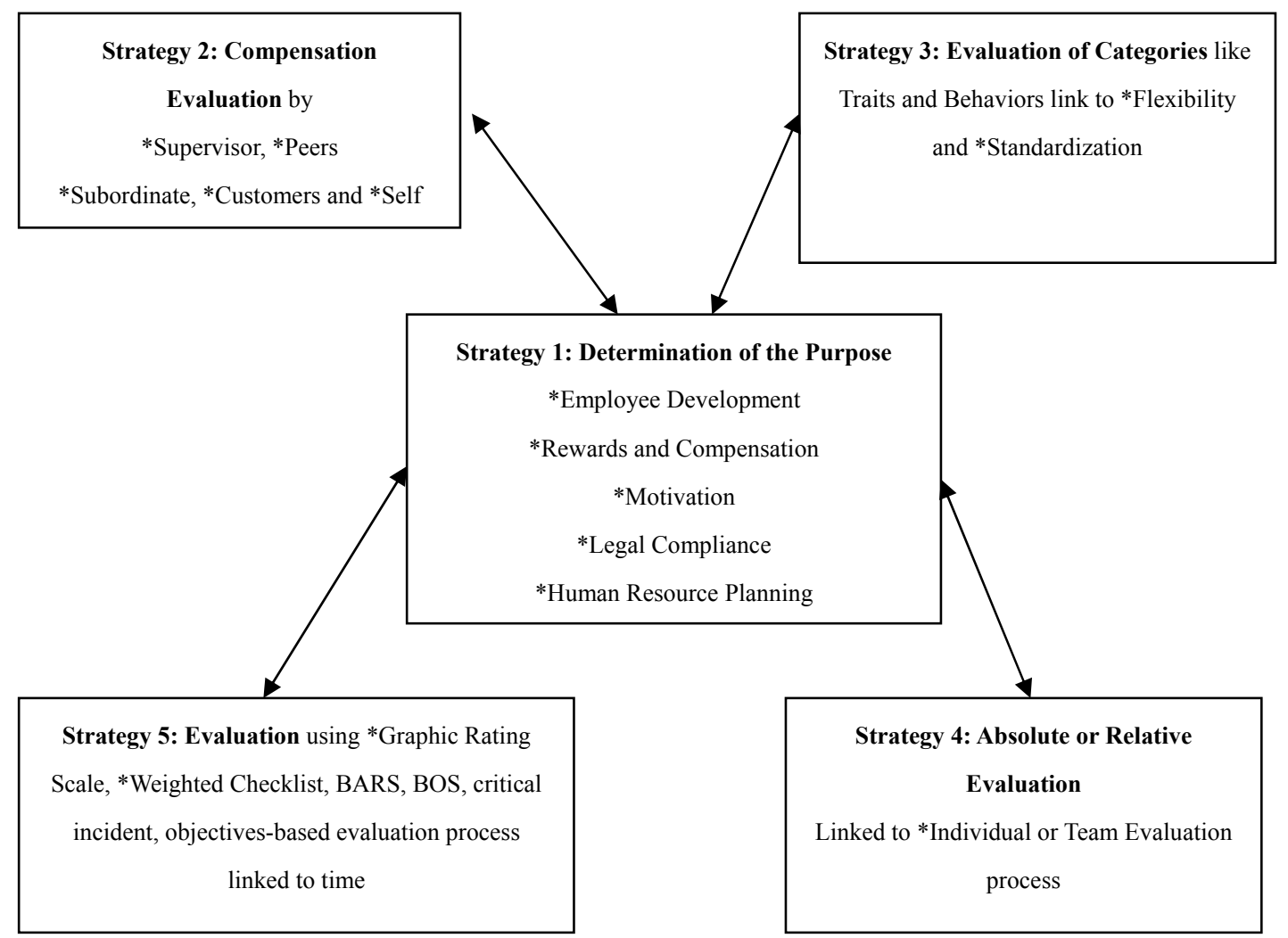

Figure 1. Five strategic decision process (Mello, 2006)

The first strategy is a determination of the purpose of the system and how it is used in the Study. It involves employee development, determines rewards and compensation, enhances motivation, facilitates legal compliance, and facilitates human resource planning.

The second strategic decision is linked with compensation, wherein, it involves somebody responsible for the evaluation process namely the supervisor, peers, subordinates, customers, and self.

The third strategic decision is about the evaluation of categories, like traits, behaviors, and results, which are linked to its flexibility and standardization.

The fourth strategic decision is the way to evaluate using absolute or relative evaluation which is linked to individual or team evaluation process.

The fifth strategic decision is the means of evaluation using objective-based evaluation process linked to time periods in the areas of graphic rating scale, weighted checklist, BARS, BOS, and critical incident, among others.

Figure 2 is the researcher's conceptual PMS strategic decisions based on Mello's (2006) five strategic decision process (Figure 1). The authors study was based on this concept involving vision, mission, value and strategy; organization and structure; employees' talent management, leadership and development: employee relations; and continuous education program. 


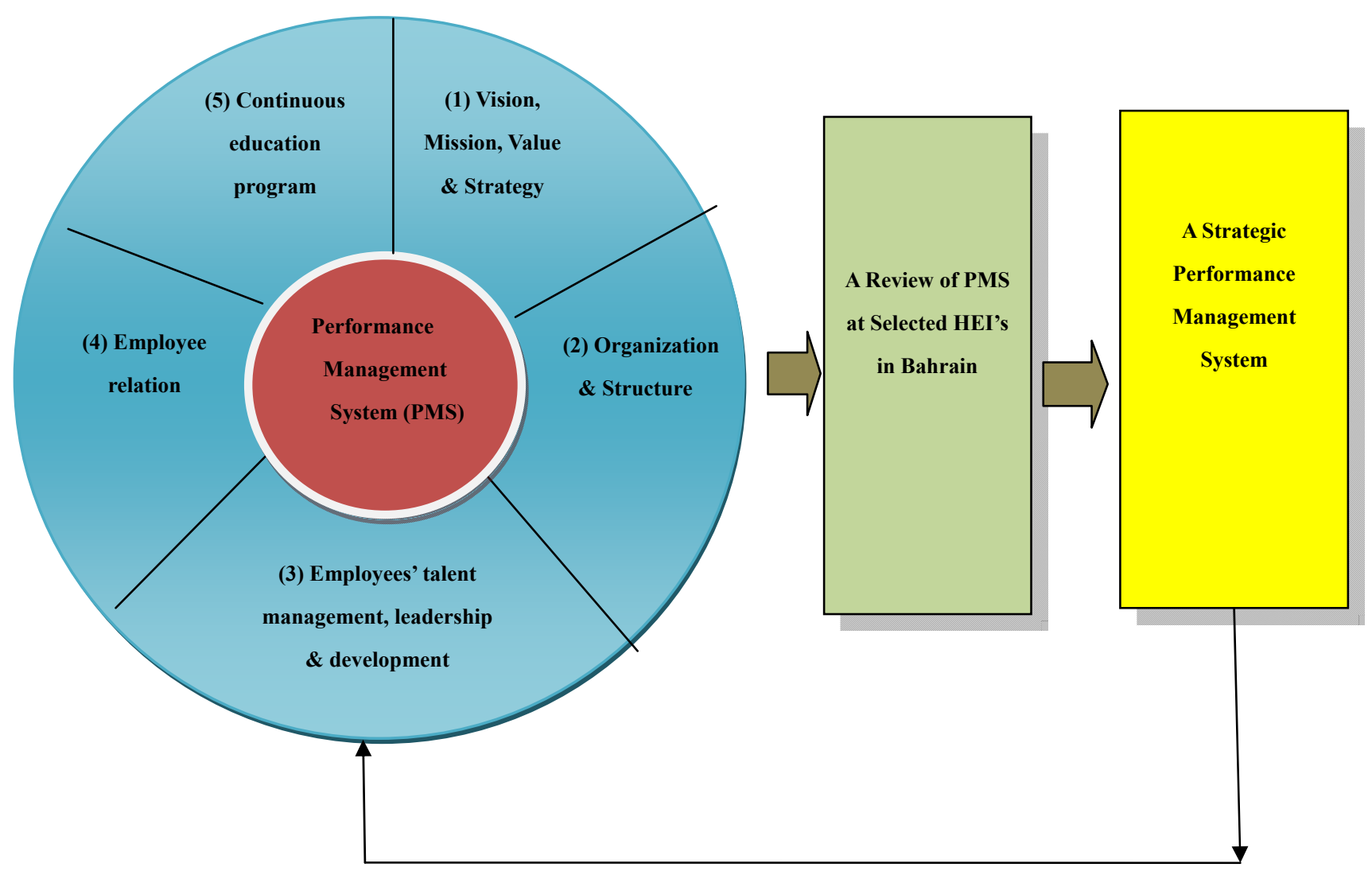

Figure 2. Strategic performance management systems

The authors add that the perspective, however, tends to ignore some very important influences on the performance management process. Noe et al. (2000) design a model of performance management in organizations which define an organizational strategy and situational constraints as shown in the following figure:

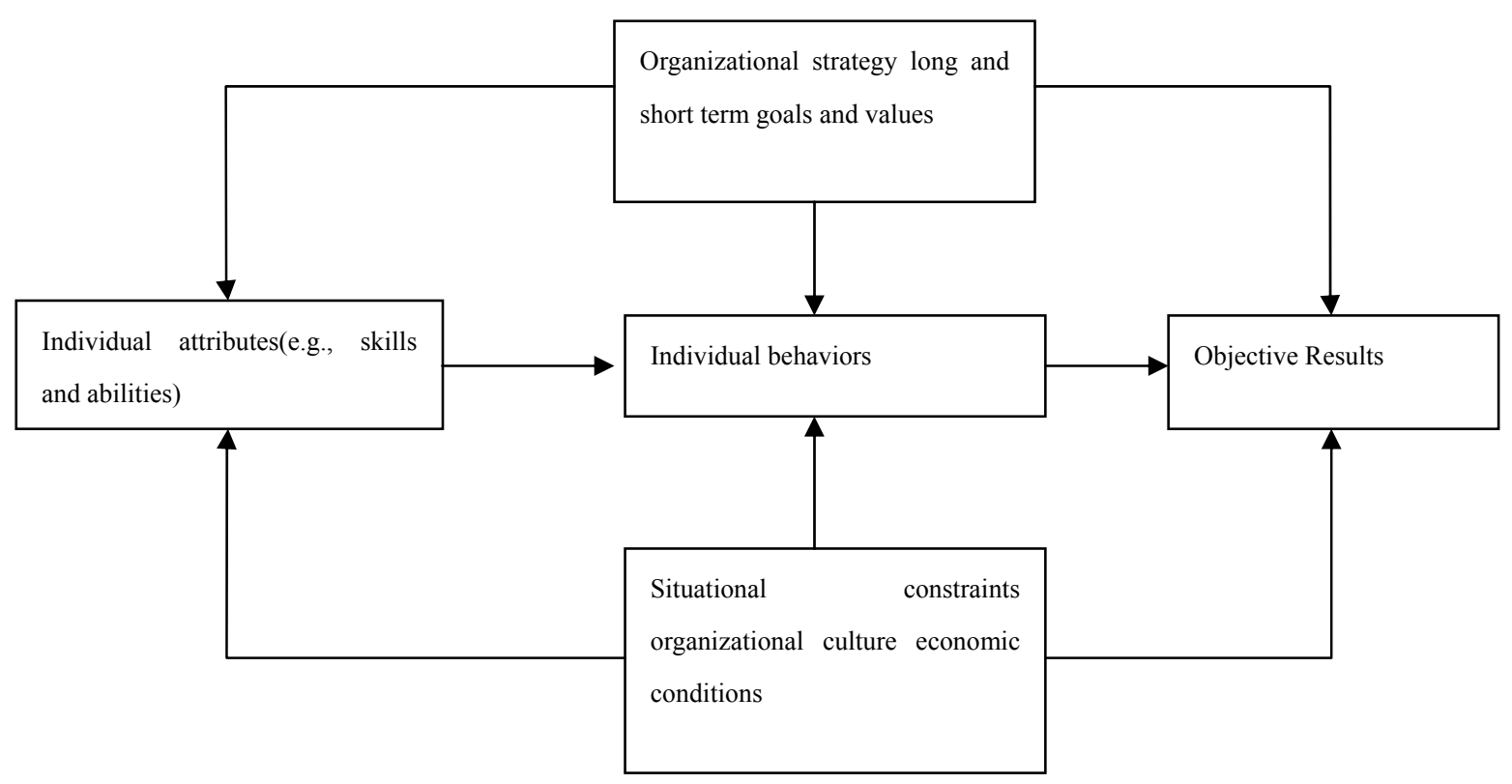

Figure 3. Performance management in organization model (Noe et al., 2000) 
The authors explain that the model shows the individual's attributes (e.g. skills and abilities) are considered the raw materials of performance. An example of this is a sales job wherein an organization wants someone who has good interpersonal skills and knowledge of the products. These raw materials are transformed into objective results through the employee's behavior. Employees can exhibit behaviors only if they have the necessary knowledge, skills, abilities, and characteristics. Thus, employees with good product knowledge and interpersonal skills can talk about the advantage of various brands and can behave in a friendly and helpful manner. On the other hand, employees with little product knowledge or interpersonal skills cannot effectively display those behaviors. The objective results are the measurable, tangible outputs of the work, and they are the consequence of the employee's or the work group's behavior. In the above example as shown by the authors, if the salesperson displays the correct behaviors, he will likely make a number of sales (Noe et al., 2000).

The authors also emphasize the importance of the organizational strategy. The link between the performance management and the organization's strategies and goals is often neglected. Most companies pursue some type of strategy to attain their revenue, profit, and market-share goals. Their contention is that departments, divisions, sections, units, work groups, and individuals within the company must align their activities with these strategies and goals. If such scheme is not aligned, then the likelihood of achieving the goals becomes small.

The author explains that in any organizations, the link has to be made primarily by specifying what needs to be accomplished and what behaviors must be exhibited for the company's strategy to be implemented. More often, this link is recognized as necessary, through the increasing popularity of performance planning and evaluation (PPE) systems. These systems link the formal performance appraisal process to the company's strategies by specifying the types and level of performance that must be accomplished to achieve the strategy at the beginning of the evaluation period. Then, at the end of the evaluation period, individuals and groups are evaluated based on how closely their actual performance meets the performance plan. In an ideal world, performance management systems would ensure that all activities support the organization's strategic goals (Noe et al., 2000).

Based on the above theoretical framework, the authors decided to come up with a research work on the performance management system on the selected higher education institutions in Bahrain.

\section{Research Methods}

This chapter deals with the review of literature in the areas of performance management system in terms of performance appraisal, promotion, rewards, and specifically: vision, mission, value and strategy; organization; employees' talent management, leadership development; employee relations; staffing; education, learning and development; and performance management. The research study used a descriptive-field survey type. This is the best design suited for the study in order to describe the existing condition of the performance management system used in the performance appraisal of the administrative manager and employees of the selected five higher education institutions in the Kingdom of Bahrain.

The study was conducted in the selected five higher education institutions in Bahrain, some private and public institutions of higher learning in the Kingdom.

These selected higher education institutions were established on their respective dates of establishments in which one of them a government and a prime institution of higher learning on May 24, 1986. This primer university was established in the late sixties during the integration of the Higher Education Institutes for male and female teachers into the system. These institutes later integrated with other colleges and formed into the primer government university. The other selected four higher education institution also were established in the late 1990s and 2000s which later been able to maintain their higher learning standards within the requirements of the Ministry of Education in Bahrain up to the present time. This research environment was based on the current locations of these selected five higher education institutions within Manama and the neighboring towns in the state nation of Bahrain where most of the employees are diversified from the academic staff to administrative employees like Bahrainis, Indians, Pakistanis, Egyptians, western people, other Asian and Arab nationalities among others. Such diversities of people working in these selected higher education institutions made it unique to this study since all of these people are affected for whatever result the performance management system will provide to them.

\subsection{Conducting Survey and Questionnaires and Findings Discussion}

This section presents in detail the discussion of the results of the study. The presentation follows the order in which the areas under the study are presented: the profile of the selected five higher education institutions (HEIs) in Bahrain's performance management system in the areas of demographic profile; vision, mission, value and strategy; organization and structure; employees, talent management, leadership development; employee relations; education, learning and development; and, performance management system; the extent in which the respondents' 
perceptions differ significantly; the identified strengths and weaknesses relevant for decision-making policies; and the kind of strategies that enhanced the selected higher education institutions' performance management system.

\subsection{PMS Profile in the Areas of Vision/Mission/Value/Strategy}

What is the profile of these selected higher education institutions in the areas of vision, mission, value and strategy? Table 1.1 shows the mean, $t$-value, $p$-value and significance of each question as perceived by the two groups of respondents, namely, the administrative managers and administrative employees. The mean of administrative managers ranges from 1.66 to 2.54 and the mean of administrative employees is from 1.60 to 2.38.

Clear Vision/Mission/Value/Strategy. The first rated question asks if everybody has a clear understanding about their university's vision, mission, value and strategy. Administrative managers were rated a mean of 1.66 with a $\mathrm{t}$-value of -10.95 and p-value of 0.058 . The weighted mean reflects to a slightly adequate and it is not significant at $\alpha=.05$. The administrative managers saw that the higher education institutions have no clear vision/mission/value and strategy and were not understood by everybody considered the statement. The administrative employees rated the mean at 1.60 with a t-value of -0.819 and p-value of 0.5629 . The weighted mean reflects to a slightly adequate and it is not significant at $\alpha=.05$. These employees found out that the higher education institutions that participated in this study have no clear vision/mission/value and strategy which reflects that is slightly adequate and not practiced.

Table 1. PMS profile: vision/mission/value/strategy

\begin{tabular}{|c|c|c|c|c|c|c|c|c|c|}
\hline & & \multicolumn{3}{|c|}{ Administrative Managers } & \multicolumn{4}{|c|}{ Administrative Employees } & \\
\hline & & \multicolumn{8}{|c|}{ Test Value: 3.5} \\
\hline & $\begin{array}{l}\text { Mission/Vision/Value } \\
\text { /Strategy }\end{array}$ & $\mathrm{mn}$ & t-val & $\mathrm{p}$-val & Remarks & $\mathrm{Mn}$ & t-val & p-val & Remarks \\
\hline 1 & $\begin{array}{l}\text { Vision/mission/value } \\
\text { and strategy statements are clear and understood by } \\
\text { everybody. }\end{array}$ & 1.66 & -10.95 & 0.058 & $\begin{array}{l}\text { Not } \\
\text { practiced }\end{array}$ & 1.60 & -0.81 & 0.562 & $\begin{array}{c}\text { Not } \\
\text { practiced }\end{array}$ \\
\hline 2 & $\begin{array}{l}\text { University's strategy for performance management is } \\
\text { clear and being implemented. }\end{array}$ & 1.82 & -21.73 & 0.029 & Practiced & 1.56 & -18 & 0.035 & Practiced \\
\hline 3 & $\begin{array}{l}\text { Individual departments in the university have their own } \\
\text { mission statements aligned to the university's } \\
\text { vision/mission/value and strategy. }\end{array}$ & 1.78 & -17.30 & 0.037 & Practiced & 1.62 & -15.1 & 0.042 & Practiced \\
\hline 4 & $\begin{array}{l}\text { University has a distinct and unique value that everybody } \\
\text { exhibits and recognized by outsiders. }\end{array}$ & 2.54 & -4.357 & 0.144 & $\begin{array}{l}\text { Not } \\
\text { practiced }\end{array}$ & 2.38 & -19.8 & 0.032 & Practiced \\
\hline 5 & $\begin{array}{l}\text { University policies and systems are well communicated } \\
\text { and adhered to by everybody. }\end{array}$ & 2.04 & -41.56 & 0.015 & Practiced & 1.82 & -4.86 & 0.129 & $\begin{array}{c}\text { Not } \\
\text { practiced }\end{array}$ \\
\hline & Grand Mean (Mission/Vision/Value/Strategy) & 1.97 & -.0015 & 0.000 & Practiced & 1.80 & -169 & 0.004 & Practiced \\
\hline
\end{tabular}

PMS Strategy and Implementation. The second concern that was rated was if the selected university's strategy for performance management is clear and being implemented. Administrative managers was rated a mean of 1.82 with a t-value of -21.73 and p-value of 0.029 . The weighted mean reflects to a slightly adequate in its being clear but practiced and significance at $\alpha=.05$.

The administrative employees rated the mean at 1.56 with a t-value of -18 and $p$-value of 0.035 . The weighted mean reflects to a slightly adequate and it is significant at $\alpha=.05$. These employees found out that the HEIs under study have no clear HEIs strategy on performance management which reflects that is slightly adequate but practiced.

Individual department's own mission statement. The third concern that was rated was if the individual department of the selected HEIs has their own mission statement aligned to the HEIs' mission. Administrative managers was rated a mean of 1.78 with a t-value of -17.30 and p-value of 0.037 . The weighted mean reflects to a slightly adequate but practiced and significance at $\alpha=.05$.

The administrative employees rated the mean at 1.62 with a $t$-value of -15.17 and $p$-value of 0.042 . The weighted mean reflects to a slightly adequate and it is significant at $\alpha=.05$. These employees found out that the HEIs under this study have their own mission statement on performance management. This reflects a slightly adequate but practiced. 
HEIs' distinct and unique value. The fourth concern that was rated was if the university has a distinct and unique value that everybody exhibits and recognized by outsiders. Administrative managers was rated a mean of 2.54 with a t-value of -4.357 and p-value of 0.144 . The weighted mean reflects to a slightly adequate but not practiced and not significance at $\alpha=.05$.

The administrative employees rated the mean at 2.38 with a t-value of -19.89 and p-value of 0.032 . The weighted mean reflects to a slightly adequate and it is significant at $\alpha=.05$. These employees found out that the HEIs being studied have a distinct and unique value that everybody exhibits and is recognized by outsiders. This reflects slightly adequate but practiced.

Well-communicated and followed HEIs' policy system. The fifth concern that was rated was if the HEI policies and systems are well communicated and adhered to by everybody. Administrative managers rated the mean at 2.04 with a t-value of -41.56 and p-value of 0.015 . The weighted mean reflects to a slightly adequate but is practiced and not significant at $\alpha=.05$.

The administrative employees rated the mean at 1.82 with a t-value of -4.862 and $p$-value of 0.129 . The weighted mean reflects to a slightly adequate and it is significant at $\alpha=.05$. These employees found out that the HEIs studied have policies and systems that are well communicated and adhered to by everybody reflecting a slightly adequate but not practiced.

\subsection{PMS Profile in the Areas of Organization and Structure}

The second PMS profile is in the areas of organization and structure. Table 1.2 shows the mean, $t$-value, $p$-value and significance of each question as perceived by the two groups of respondents such as the administrative managers and administrative employees. The mean of administrative managers ranges from 1.68 to 2.80 and the mean of administrative employees is from 1.45 to 2.78 .

Formal Structure at par with international higher education institutions. The first concern was the university's formal structure at par with international higher education institutions. Administrative managers rated this concern with a mean of 2.88 interpreted as moderately adequate or weakness with a t-value of -4.07 and p-value of 0.153 and not significant at $\alpha=.05$. The administrative managers saw that the university has a formal structure at par with international higher education institutions but is moderately adequate and not practiced.

Table 2. PMS profile: organization and structure

\begin{tabular}{|c|c|c|c|c|c|c|c|c|c|}
\hline & & \multicolumn{3}{|c|}{ Administrative Managers } & \multicolumn{4}{|c|}{ Administrative Employees } & \\
\hline & & \multicolumn{8}{|c|}{ Test Value: 3.5} \\
\hline & Organization \& Structure & $\mathrm{Mn}$ & t-val & p-val & Remarks & $\mathrm{Mn}$ & t-val & p-val & Remarks \\
\hline 1 & $\begin{array}{l}\text { University has a formal structure at par with } \\
\text { international higher education institutions. }\end{array}$ & 2.8 & -4.07 & 0.153 & $\begin{array}{l}\text { Not } \\
\text { practiced }\end{array}$ & 2.78 & -2.469 & 0.245 & $\begin{array}{l}\text { Not } \\
\text { practiced }\end{array}$ \\
\hline 2 & $\begin{array}{l}\text { Functional relationships among departments are } \\
\text { clearly defined and delineated. }\end{array}$ & 2.42 & -29.42 & 0.022 & Practiced & 2.54 & -3.0 & 0.205 & $\begin{array}{l}\text { Not } \\
\text { practiced }\end{array}$ \\
\hline 3 & $\begin{array}{l}\text { Job descriptions for all positions are clear and } \\
\text { followed. }\end{array}$ & 2.02 & -8.136 & 0.078 & $\begin{array}{l}\text { Not } \\
\text { practiced }\end{array}$ & 1.96 & -5.0 & 0.126 & $\begin{array}{l}\text { Not } \\
\text { practiced }\end{array}$ \\
\hline 4 & $\begin{array}{l}\text { Performance evaluation is communicated and done } \\
\text { regularly. }\end{array}$ & 1.68 & -4.482 & 0.124 & $\begin{array}{l}\text { Not } \\
\text { practiced }\end{array}$ & 1.449 & -29.8 & 0.021 & Practiced \\
\hline 5 & $\begin{array}{l}\text { All managers and employees know about the } \\
\text { purpose of performance management. }\end{array}$ & 2.8 & -4.07 & 0.153 & $\begin{array}{l}\text { Not } \\
\text { practiced }\end{array}$ & 1.56 & -5.721 & 0.11 & $\begin{array}{l}\text { Not } \\
\text { practiced }\end{array}$ \\
\hline & Grand Mean (Organization \& Structure) & 2.34 & -11.25 & 0.008 & Practiced & 2.059 & -21.57 & 0.029 & Practiced \\
\hline
\end{tabular}

The administrative employees rated the mean at 2.78 which means that it is moderately adequate and is interpreted as a weakness with a $t$-value of -4.07 and $p$-value of 0.153 . It is not significant at $\alpha=.05$. These employees found out that the university has a formal structure at par with international higher education institutions that is moderately adequate but not practiced.

Clearly defined functional relationships among departments. The second concern was the functional relationships among departments with clear definition and delineation. Administrative managers rated this concern with a mean of 2.42, which is interpreted as slightly adequate or weak but practiced with a t-value of -29.42 and p-value of 0.022 and significant at $\alpha=.05$. The administrative managers saw that there was a functional relationship among departments and is clearly defined and delineated. 
The administrative employees rated the mean at 2.54 . This means moderately adequate and is interpreted as a weakness with a t-value of -3.0 and $p$-value of 0.205 . It is not significant at $\alpha=.05$. These administrative employees found out that there were functional relationships among departments and it is clearly defined and delineated but moderately adequate and not practiced.

Clear job descriptions and implemented. The third concern was the job descriptions for all positions that are clear and followed. Administrative managers rated this concern with a mean of 2.02 meaning slightly adequate, which is interpreted as a weakness with a $\mathrm{t}$-value of -8.136 and $\mathrm{p}$-value of 0.078 and not significant at $\alpha=.05$. The administrative managers saw that job descriptions for all positions are clear and not practiced.

The administrative employees rated the mean at 1.96 which means slightly adequate interpreted as a weakness with a $t$-value of -5.0 and $p$-value of 0.126 . It is not significant at $\alpha=.05$. These administrative employees found out that job descriptions for all positions are clear and not practiced.

Regular performance evaluation. The fourth concern was the performance evaluation being communicated and done regularly. Administrative managers rated this concern with a mean of 1.68 meaning slightly adequate, which is interpreted as a weakness with a t-value of -4.482 and $p$-value of 0.124 and not significant at $\alpha=.05$. The administrative managers saw that performance evaluation is not communicated and done regularly. The administrative employees rated the mean at 1.449 meaning inadequate that is interpreted as a weakness with a $\mathrm{t}$-value of -29.8 and $\mathrm{p}$-value of 0.021 . It is significant at $\alpha=.05$. These administrative employees found out that performance evaluation was being communicated and done regularly.

Knowledge of performance management. The fifth concern was that all managers and employees know about the purpose of performance management. Administrative managers rated this concern with a mean of 2.8 meaning moderately adequate, which is interpreted as a weakness with a t-value of -4.07 and p-value of 0.153 and not significant at $\alpha=.05$. The administrative managers saw that all managers and employees know about the purpose of performance management. The administrative employees rated the mean at 1.56 meaning slightly adequate that is interpreted as a weakness with a t-value of -5.721 and $p$-value of 0.11 . It is not significant at $\alpha=.05$. These administrative employees found out that all managers and employees know about the purpose of performance management but failed to practice.

\subsection{PMS Profile in the Areas of Employees'}

\subsubsection{Talent Management and Leadership Development}

The third PMS profile of these selected higher education institutions operating in Bahrain's performance management system is in the areas of employees' talent management and leadership development. Table 1.3 shows the mean, t-value, $p$-value and significance of each question as perceived by the two groups of respondents such as the administrative managers and administrative employees. The mean of administrative managers ranges from 1.82 to 3.29 and the mean of administrative employees is from 1.70 to 3.30 .

Employee's involvement in the review, development and implementation of PMS. The first concern was that all employees are involved actively in the review, development and implementation of the PMS. Administrative managers rated this concern with a mean of 3.29 meaning moderately adequate which is interpreted as a weakness with a $\mathrm{t}$-value of -2.68 and $\mathrm{p}$-value of 0.116 and not significant at $\alpha=.05$. The administrative managers saw that employees are not involved actively in the review, development and implementation of the PMS shown in the table.

The administrative employees rated the mean at 2.94 meaning moderately adequate which is interpreted as a weakness with a t-value of -3.815 and $p$-value of 0.062 . It is not significant at $\alpha=.05$. These administrative employees found out that employees are not involved actively in the review, development and implementation of the PMS shown in the table.

Strong administrative support to employees. The second concern was that employees are given strong administrative support to enhance their present management skills and possess strong work ethics and qualifications. Administrative managers rated this concern with a mean of 2.14 meaning slightly adequate which is interpreted as a weakness with a t-value of -15.73 and $p$-value of 0.003 and significant at $\alpha=.05$. The administrative managers saw that employees are given strong administrative support to enhance their present management skills and possess strong work ethics and qualifications as shown in the table. 
Table 3. PMS profile: employees' talent management and leadership

\begin{tabular}{|c|c|c|c|c|c|c|c|c|c|}
\hline & & Admi & istrative & Manager & & nistrat & re Emp & yees & \\
\hline & & Test & lue: 3.5 & & & & & & \\
\hline & Employees' Talent & $\mathrm{Mn}$ & t-val & p-val & Remarks & $\mathrm{Mn}$ & t-val & p-val & Remarks \\
\hline 1 & $\begin{array}{l}\text { Employees are involved actively in the review, } \\
\text { development and implementation of the PMS. }\end{array}$ & 3.29 & 2.68 & 0.116 & $\begin{array}{c}\text { Not } \\
\text { practice }\end{array}$ & 2.94 & 3.815 & 0.062 & $\begin{array}{c}\text { Not } \\
\text { practice }\end{array}$ \\
\hline 2 & $\begin{array}{l}\text { Employees are given strong administrative support to } \\
\text { enhance their present management skills and possess } \\
\text { strong work ethics and qualifications. }\end{array}$ & 2.14 & 15.73 & 0.003 & Practice & 2.14 & 13.59 & 0.005 & Practice \\
\hline 3 & $\begin{array}{l}\text { Employees have natural leadership traits that are } \\
\text { developed creatively by management likewise creative } \\
\text { and innovative in their decision-making activities. }\end{array}$ & 2.00 & 6.692 & 0.094 & $\begin{array}{c}\text { Not } \\
\text { practice }\end{array}$ & 1.78 & 4.733 & 0.133 & $\begin{array}{c}\text { Not } \\
\text { practice }\end{array}$ \\
\hline 4 & $\begin{array}{l}\text { Career paths for all employees are well defined, } \\
\text { communicated and implemented as well as succession } \\
\text { plan is in place. }\end{array}$ & 1.82 & 4.895 & 0.136 & $\begin{array}{c}\text { Not } \\
\text { practice }\end{array}$ & 1.70 & 4733 & 0.136 & $\begin{array}{c}\text { Not } \\
\text { practice }\end{array}$ \\
\hline 5 & $\begin{array}{l}\text { Performance development plans and formal procedure for } \\
\text { identifying potential leaders are being instituted for } \\
\text { everybody and supported by senior management. }\end{array}$ & 2.71 & 5.938 & 0.106 & $\begin{array}{c}\text { Not } \\
\text { practice }\end{array}$ & 3.30 & 4.294 & 0.146 & $\begin{array}{c}\text { Not } \\
\text { practice }\end{array}$ \\
\hline & Grand Mean (Employees' Talent) & 2.39 & 6842 & 0.092 & Practice & 2.38 & 6.6 & 0.096 & $\begin{array}{c}\text { Not } \\
\text { practice }\end{array}$ \\
\hline
\end{tabular}

The administrative employees rated the mean at 2.14 meaning slightly adequate which is interpreted as a weakness with a t-value of -13.59 and $p$-value of 0.005 . It is not significant at $\alpha=.05$. These administrative employees found out that employees are given strong administrative support to enhance their present management skills and possess strong work ethics and qualifications as shown in the table.

Employee's natural leadership. The third concern was that employees have natural leadership traits that are developed creatively by management likewise creative and innovative in their decision-making activities. Administrative managers rated this concern with a mean of 2.00 meaning slightly adequate which is interpreted as a weakness with a t-value of -6.692 and p-value of 0.094 and significant at $\alpha=.05$. The administrative managers saw that employees have natural leadership traits that are developed creatively by management likewise creative and innovative in their decision-making activities but unfortunately not practiced.

The administrative employees rated the mean at 1.78 meaning slightly adequate which is interpreted as a weakness with a t-value of -4.733 and $p$-value of 0.133 . It is not significant at $\alpha=.05$. These administrative employees found out that employees have natural leadership traits that are developed creatively by management likewise creative and innovative in their decision-making activities but unfortunately not practiced.

Employee's natural leadership. The fourth concern was that career paths for all employees are well defined, communicated and implemented as well as succession plan is in place. Administrative managers rated this concern with a mean of 1.82 meaning slightly adequate which is interpreted as a weakness with a t-value of -4.895 and $\mathrm{p}$-value of 0.136 and not significant at $\alpha=.05$. The administrative managers saw that career paths for all employees are not well defined, not communicated and not implemented as well as succession plan is not in place as shown in the table.

The administrative employees rated the mean at 1.70 meaning slightly adequate which is interpreted as a weakness with a t-value of -4.733 and $p$-value of 0.136 . It is not significant at $\alpha=.05$. These administrative employees found out that employees have natural leadership traits that career paths for all employees are not well defined, not communicated and not implemented as well as succession plan is not in place as shown in the table.

Institute performance development plans. The fifth concern was that performance development plans and formal procedure for identifying potential leaders are being instituted for everybody and supported by senior management. Administrative managers rated this concern with a mean of 2.71 meaning moderately adequate which is interpreted as a weakness with a t-value of -5.938 and $p$-value of 0.106 and not significant at $\alpha=.05$. The administrative managers saw that performance development plans and formal procedure for identifying potential leaders are not being instituted for everybody and not supported by senior management as shown in the table. The administrative employees rated the mean at 3.30 meaning moderately adequate which is interpreted as a weakness with a t-value of -4.294 and $p$-value of 0.146. It is not significant at $\alpha=.05$. These administrative employees found out that performance development plans and formal procedure for identifying potential leaders are not being instituted for 
everybody and not supported by senior management as shown in the table.

\subsection{PMS Profile in the Areas of Employee Relations}

The fourth PMS profile of these selected five higher education institutions operating in Bahrain's performance management system is in the area of employee relations. Table 4.8 shows the mean, $t$-value, $p$-value and significance of each question as perceived by the two groups of respondents such as the administrative managers and administrative employees. The mean of administrative managers ranges from 1.46 to 2.46 and the mean of administrative employees is from 1.46 to 3.3 .

Table 4. PMS profile: employee relations

\begin{tabular}{|c|c|c|c|c|c|c|c|c|c|}
\hline & & \multicolumn{3}{|c|}{ Administrative Managers } & \multicolumn{4}{|c|}{ Administrative Employees } & \multirow[b]{3}{*}{ Remarks } \\
\hline & & \multicolumn{7}{|c|}{ Test Value: 3.5} & \\
\hline & Employee Relations & $\mathrm{Mn}$ & t-val & p-val & Remarks & $\mathrm{Mn}$ & t-val & p-val & \\
\hline 1 & $\begin{array}{l}\text { HR office reviews and advises employees for interrelation } \\
\text { with their co-employees. }\end{array}$ & 2.12 & 5.933 & 0.106 & $\begin{array}{c}\text { Not } \\
\text { practice }\end{array}$ & 2.06 & 6.6 & 0.096 & $\begin{array}{c}\text { Not } \\
\text { practice }\end{array}$ \\
\hline 2 & $\begin{array}{l}\text { HR office reviews and advises employees for company } \\
\text { regulations and company developments. }\end{array}$ & 2.46 & 5.0 & 0.126 & $\begin{array}{c}\text { Not } \\
\text { practice }\end{array}$ & 2.96 & 55 & 0.012 & Practice \\
\hline 3 & $\begin{array}{l}\text { HR office reviews and advises employees for companies } \\
\text { outside regulations such as the government's regulatory } \\
\text { policies and laws. }\end{array}$ & 2.06 & 5.0 & 0.126 & $\begin{array}{c}\text { Not } \\
\text { practice }\end{array}$ & 2.32 & 3 & 0.205 & $\begin{array}{c}\text { Not } \\
\text { practice }\end{array}$ \\
\hline 4 & $\begin{array}{l}\text { Well documented policies and procedures are well } \\
\text { communicated and understood by all employees. }\end{array}$ & 1.46 & 7.5 & 0.084 & $\begin{array}{c}\text { Not } \\
\text { practice }\end{array}$ & 3.3 & 1.455 & 0.383 & $\begin{array}{c}\text { Not } \\
\text { practice }\end{array}$ \\
\hline 5 & $\begin{array}{l}\text { Employee handbook on rules, regulations, entitlement, } \\
\text { benefits, etc. are provided to employees. }\end{array}$ & 1.6 & 10.18 & 0.62 & $\begin{array}{c}\text { Not } \\
\text { practice }\end{array}$ & 1.46 & 1.455 & 0.383 & $\begin{array}{c}\text { Not } \\
\text { practice }\end{array}$ \\
\hline & $\begin{array}{l}\text { Grand Mean } \\
\text { (Employee Relations) }\end{array}$ & 1.94 & 43.57 & 0.015 & Practice & 2.42 & 5.909 & 0.107 & $\begin{array}{c}\text { Not } \\
\text { practice }\end{array}$ \\
\hline
\end{tabular}

A reviews and advices employee for interrelation with employees the first concern was that HR office reviews and advises employees for interrelation with their co-employees. Administrative managers rated this concern with a mean of 2.12 meaning slightly adequate which is interpreted as a weakness with a t-value of -5.933 and p-value of 0.106 and not significant at $\alpha=.05$. The administrative managers saw that HR office did not review and advise employees for interrelation with their co-employees as shown in the table of not being practiced.

The administrative employees rated the mean at 2.06 meaning slightly adequate which is interpreted as a weakness with a t-value of -6.6 and $p$-value of 0.096. It is not significant at $\alpha=.05$. These administrative employees found out that HR office did not review and advise employees for interrelation with their co-employees as shown in the table of not being practiced.

Reviews and advices employees for company regulations and developments. The second concern was that HR office reviews and advises employees for company regulations and company developments. Administrative managers rated this concern with a mean of 2.46 meaning slightly adequate which is interpreted as weakness with a t-value of -5.0 and $p$-value of 0.126 and not significant at $\alpha=.05$. The administrative managers saw that HR office failed to review and failed to advice employees for company regulations and company developments as seen.

The administrative employees rated the mean at 2.96 meaning moderately adequate which is interpreted as weakness with a t-value of -55 and $p$-value of 0.012 . It is not significant at $\alpha=.05$. These administrative employees found out that HR office HR office reviews and advices employees for company regulations and company developments as seen in the table.

HR advices on government's regulations. The third concern was that HR office reviews and advises employees for companies outside regulations such as the government's regulatory policies and laws. Administrative managers rated this concern with a mean of 2.06 meaning slightly adequate which is interpreted as a weakness with a t-value of -5.0 and $p$-value of 0.126 and not significant at $\alpha=.05$. The administrative managers saw that HR office reviews and advises employees for companies outside regulations such as the government's regulatory policies and laws.

The administrative employees rated the mean at 2.32 meaning slightly adequate which is interpreted as a weakness with a t-value of -3 and $p$-value of 0.205 . It is not significant at $\alpha=.05$. These administrative employees found out 
that HR office reviews and advises employees for companies outside regulations such as the government's regulatory policies and laws.

Well-documented policies and procedures. The fourth concern was that well-documented policies and procedures are well communicated and understood by all employees. Administrative managers rated this concern with a mean of 1.46 meaning inadequate which is interpreted as a weakness with a t-value of -7.5 and p-value of 0.084 and not significant at $\alpha=.05$. The administrative managers saw that well-documented policies and procedures are not well-communicated and understood by all employees as shown in the table.

The administrative employees rated the mean at 3.3 meaning moderately adequate which is interpreted as a weakness with a t-value of -1.455 and $p$-value of 0.383 . It is not significant at $\alpha=.05$. These administrative employees found out that well-documented policies and procedures are not well-communicated and understood by all employees as shown in the table.

Employee handbook. The fifth concern was that employee handbook on rules, regulations; entitlement, benefits, etc. are provided to employees. Administrative managers rated this concern with a mean of 1.6 meaning slightly adequate which is interpreted as a weakness with a t-value of -10.18 and p-value of 0.62 and not significant at $\alpha$ $=.05$. The administrative managers saw that employee handbook on rules, regulations, entitlement, benefits, etc. are not provided to employees as shown in the table.

The administrative employees rated the mean at 1.46 meaning inadequate which is interpreted as a weakness with a t-value of -1.455 and $p$-value of 0.383 . It is not significant at $\alpha=.05$. These administrative employees found out that employee handbook on rules, regulations, entitlement, benefits, etc. are not provided to employees as shown in the table.

\subsection{PMS Profile in the Areas of Staffing}

The fifth PMS profile of these selected higher education institutions operating in Bahrain's performance management system is in the area of staffing.

Table 1.5 shows the mean, $t$-value, $p$-value and significance of each question as perceived by the two groups of respondents such as the administrative managers and administrative employees. The mean of administrative managers ranges from 1.46 to 2.46 and the mean of administrative employees is from 1.16 to 2.56.

University provides equal opportunities to everybody. The first concern was that the university provided equal opportunities to everybody. Administrative managers rated this concern with a mean of 2.48 meaning slightly adequate which is interpreted as a weakness with a t-value of -5.08 and p-value of 0.124 and not significant at $\alpha$ $=.05$. The administrative managers observed that this was not practiced as shown in the table. The administrative employees rated the mean at 2.54 meaning moderately adequate which is interpreted as a weakness with a $t$-value of 4.43 and p-value of 0.141 . It is not significant at $\alpha=.05$. These administrative employees found out that equal opportunities provided to everybody were not being practiced.

The administrative employees rated the mean at 2.65 meaning moderately adequate which is interpreted as a weakness with a t-value of -4.429 and p-value of 0.141 . It is not significant at $\alpha=.05$. These administrative employees found out that this concern was not also practiced as seen in the table.

Recruitment through advertisements, internal referrals, etc. The third concern was that recruitment was being done through advertisements, internal referrals, and outside solicitation through friends, and the internet among others. Administrative managers rated this concern with a mean of 1.16 meaning inadequate which is interpreted as a weakness with a t-value of -4.707 and $p$-value of 0.133 and not significant at $\alpha=.05$. The administrative managers saw that this concern was not practiced.

The administrative employees rated the mean at 1.04 meaning inadequate which is interpreted as a weakness with a t-value of -3.537 and $p$-value of 0.175 . It is not significant at $\alpha=.05$. These administrative employees found out that this concern is not practiced.

Implementation of recruitment and selection policies. The fourth concern was that recruitment and selection policies are well in placed and well-implemented. Administrative managers rated this concern with a mean of 1.92 meaning slightly adequate which is interpreted as a weakness with a t-value of -51.67 and p-value of 0.012 and significant at $\alpha=.05$. The administrative managers saw that concern is not practiced as seen.

The administrative employees rated the mean at 2.0 meaning slightly adequate which is interpreted as a weakness with a t-value of -4.234 and $p$-value of 0.148 . It is not significant at $\alpha=.05$. These administrative employees found out that this concern is not practiced.

Human resource planning as a basis for staffing. The fifth concern was that human resource planning is being done 
and used as a basis for staffing. Administrative managers rated this concern with a mean of 1.76 meaning slightly adequate which is interpreted as a weakness with a t-value of -14.82 and $p$-value of 0.043 and significant at $\alpha=.05$. The administrative managers saw that the human resource planning is being done and used as a basis for staffing as shown in the table.

The administrative employees rated the mean at 1.66 meaning slightly adequate which is interpreted as a weakness with a $t$-value of -151 and $p$-value of 0.004 . It is significant at $\alpha=.05$. These administrative employees found out that this concern is being practiced.

\subsection{PMS Profile in the Area of Continuous Education Program}

The sixth PMS profile of these selected higher education institutions operating in Bahrain's performance management system is in the areas of education, learning and development. Table 4.10 shows the mean, t-value, p-value and significance of each question as perceived by the two groups of respondents such as the administrative managers and administrative employees. The mean of administrative managers ranges from 1.48 to 2.08 and the mean of administrative employees is from 1.48 to 1.68 .

Training Policy. The first concern was that training policy is well laid out including the training calendar with sufficient budget appropriation and being conducted in-house, external or both. Administrative managers rated this concern with a mean of 1.96 meaning slightly adequate interpreted as weakness with a t-value of -18.11 and $\mathrm{p}$-value of 0.035 and significant at $\alpha=.05$. The administrative managers observed that this was practiced as shown in the table.

The administrative employees rated the mean at 1.68 meaning slightly adequate interpreted as weakness with a $\mathrm{t}$-value of -11.13 and $\mathrm{p}$-value of 0.057 . It is not significant at $\alpha=.05$. These administrative employees found out that this concern is not being practiced.

Average Training Policy. The second concern was that the average training cost as percentage to total staff cost including payroll, benefits, etc. is in the parameters of $1 \%$, or $1 \%$ to $3 \%$, or $4 \%$ to $5 \%$ and or over $5 \%$. Administrative managers rated this concern with a mean of 2.08 meaning slightly adequate interpreted as weakness with a t-value of -10.47 and $p$-value of 0.061 and significant at $\alpha=.05$. The administrative managers observed that this was not practiced as shown in the table.

The administrative employees rated the mean at 1.67 meaning slightly adequate interpreted as weakness with a $\mathrm{t}$-value of -41.11 and $\mathrm{p}$-value of 0.015 . It is not significant at $\alpha=.05$. These administrative employees found out that this concern is being practiced.

Table 5. PMS profile: continuous education program

\begin{tabular}{|c|c|c|c|c|c|c|c|c|c|}
\hline & & \multicolumn{3}{|c|}{ Administrative Managers } & \multicolumn{4}{|c|}{ Administrative Employees } & \multirow[b]{3}{*}{ Remarks } \\
\hline & & \multicolumn{7}{|c|}{ Test Value: 3.5} & \\
\hline & Continuous Education & $\mathrm{Mn}$ & t-val & $\mathrm{p}$-val & Remarks & $\mathrm{Mn}$ & $\mathrm{t}$-val & p-val & \\
\hline 1 & $\begin{array}{l}\text { Training policy is well laid out including the training } \\
\text { calendar with sufficient budget appropriation and being } \\
\text { conducted in-house, external or both. }\end{array}$ & 1.96 & -18.1 & 0.035 & Practiced & 1.68 & -11.1 & 0.057 & $\begin{array}{c}\text { Not } \\
\text { Practiced }\end{array}$ \\
\hline 2 & $\begin{array}{l}\text { Average training cost as percentage (\%) to total staff cost } \\
\text { (payroll, benefits, etc.) is in the parameters of: below } \\
1 \%, 1 \% \text { to } 3 \%, 4 \% \text { to } 5 \% \text {, and over } 5 \% \text {. }\end{array}$ & 2.08 & -10.47 & 0.061 & $\begin{array}{c}\text { Not } \\
\text { Practiced }\end{array}$ & 1.67 & -41.44 & 0.015 & Practiced \\
\hline 3 & $\begin{array}{l}\text { Average training man-days per employee is within the } \\
\text { minimum of } 1 \text { day and over ten days. }\end{array}$ & 1.48 & -12.46 & 0.057 & $\begin{array}{c}\text { Not } \\
\text { Practiced }\end{array}$ & 1.52 & -55.57 & 0.011 & Practiced \\
\hline 4 & $\begin{array}{l}\text { Following programs were utilized to all levels of } \\
\text { employees in determining the training needs such as } \\
\text { competency analysis, performance appraisal, etc. }\end{array}$ & 1.86 & -42 & 0.015 & Practiced & 1.6 & -3.51 & 0.002 & Practiced \\
\hline 5 & $\begin{array}{l}\text { Contents of the training programs are being reviewed } \\
\text { periodically in accordance with the company's roles and } \\
\text { need, e.g., once a year, once in every } 2 \text { or } 3 \text { years, when } \\
\text { requested, or when there is an urgent need. }\end{array}$ & 1.5 & -13.29 & 0.048 & Practiced & 1.48 & -35.73 & 0.18 & $\begin{array}{c}\text { Not } \\
\text { Practiced }\end{array}$ \\
\hline & $\begin{array}{l}\text { Grand Mean } \\
\text { (Continuous Education) }\end{array}$ & 1.78 & -13.96 & 0.046 & Practiced & 1.98 & -1014 & 0.001 & Practiced \\
\hline
\end{tabular}


Average Training Man-days. The third concern was that the average training man-days per employee is within the minimum of 1 day and over ten days. Administrative managers rated this concern with a mean of 1.48 meaning inadequate interpreted as weakness with a t-value of -12.46 and $p$-value of 0.057 and not significant at $\alpha=.05$. The administrative managers observed that this was not practiced as shown in the table.

The administrative employees rated the mean at 1.52 meaning slightly adequate interpreted as weakness with a $\mathrm{t}$-value of -55.57 and $\mathrm{p}$-value of 0.011 . It is significant at $\alpha=.011$. These administrative employees found out that this concern is being practiced.

Programs in Training Goods. The fourth concern were the programs being utilized to all levels of employees in determining the training needs such as competency analysis, performance appraisal, established training modules, independent need, identification, productivity/performance report, technology, and infrastructure change among others. Administrative managers rated this concern with a mean of 1.86 meaning slightly adequate interpreted as weakness with a t-value of -42 and $p$-value of 0.015 and significant at $\alpha=.05$. The administrative managers observed that this was practiced as shown in the table.

The administrative employees rated the mean at 1.6 meaning slightly adequate interpreted as weakness with a $\mathrm{t}$-value of -3.51 and $p$-value of 0.002 . It is significant at $\alpha=.05$. These administrative employees found out that this concern is being practiced.

Periodic Review of Training Program. The fourth concern was the periodic review of contents of the training programs in accordance with the company's roles and need, e.g., once a year, once in every 2 or 3 years, when requested, or when there is an urgent need. Administrative managers rated this concern with a mean of 1.5 meaning slightly adequate interpreted as weakness with a t-value of -13.29 and $p$-value of 0.048 and significant at $\alpha=.05$. The administrative managers observed that this was practiced as shown in the table.

The administrative employees rated the mean at 1.48 meaning inadequate interpreted as weakness with a $t$-value of -35.73 and $p$-value of 0.18 . It is not significant at $\alpha=.05$. These administrative employees found out that this concern is not being practiced.

\subsection{PMS Profile in the Area of Performance Management System}

The seventh PMS profile is in the area of performance management system shown in Table 6.

Periodic Conduct of Employee Satisfaction Surveys or Performance Cycle. The first concern was employee satisfaction surveys or performance assessment cycle being conducted periodically, e.g., quarterly, bi-annually, and annually using established criteria. Administrative managers and Administrative employees rated this concern with a mean of 1.46 meaning inadequate interpreted as weakness with a t-value of -20.47 and $p$-value of 0.031 and not significant at $\alpha=.05$. The administrative managers saw that this concern was being practiced

The Use of Key Performance Indicators (KPIs). The second concern was the use of key performance indicators (KPIs) in all functions, positions and other criteria that will enhance system. Administrative managers rated this concern with a mean of 1.76 meaning slightly adequate interpreted as weakness with a t-value of -32.64 and $\mathrm{p}$-value of 0.02 and significant at $\alpha=.05$. The administrative managers saw that concern is being practiced as seen.

The administrative employees rated the mean at 1.76 meaning slightly adequate interpreted as weakness with a $\mathrm{t}$-value of -20.47 and $\mathrm{p}$-value of 0.031 . It is significant at $\alpha=.05$. These administrative employees found out that this concern is being practiced.

Performance Assessment Mechanism. The third concern was the individuals were coached, mentored, and counseled as part of performance assessment mechanism in order to enhance the employees' job performance. Both the administrative managers and administrative employees rated this concern with a mean of 1.46 meaning inadequate interpreted as weakness with a t-value of -20.47 and p-value of 0.031 and not significant at $\alpha=.05$. Both saw that this concern was being practiced.

Creating a Performance Development Plan. The fourth concern was that performance development plan was being created as well as behavioral appraisal and employee feedbacks are being conducted to develop employee potentials. Administrative managers rated this concern with a mean of 1.7 meaning slightly adequate interpreted as weakness with a t-value of -73 and $p$-value of 0.009 and significant at $\alpha=.05$. The administrative managers saw that this plan was practiced.

The administrative employees rated the mean at 1.7 meaning slightly adequate interpreted as weakness with a $\mathrm{t}$-value of -20.47 and $\mathrm{p}$-value of 0.031 . It is significant at $\alpha=.05$. These administrative employees found out that this concern was being practiced.

Players Involvement in an Individual's Performance Assessment. The fifth concern was that employee, immediate 
superior, department head, and staff were the players involved in an individual's performance assessment.

Administrative managers rated this concern with a mean of 1.88 meaning slightly adequate interpreted as weakness with a t-value of -15.09 and $p$-value of 0.042 and significant at $\alpha=.05$. The administrative managers saw that this plan was practiced.

The administrative employees rated the mean at 1.88 meaning slightly adequate interpreted as weakness with a $\mathrm{t}$-value of -73 and $\mathrm{p}$-value of 0.009 . It is significant at $\alpha=.05$. These administrative employees found out that this concern was being practiced.

Vision/Mission/Value and Strategy. This first profile of the performance management system in the areas of vision, mission, value and strategy show the following result: Administrative managers rated this concern with a mean of 1.97 meaning slightly adequate interpreted as weakness with a t-value of -110.4 and p-value of 0.006 and significant at $\alpha=.05$. The administrative managers saw that this profile was being practiced.

The administrative employees rated the mean at 1.8 meaning slightly adequate interpreted as weakness with a $\mathrm{t}$-value of -27.33 and $\mathrm{p}$-value of 0.023 . It is significant at $\alpha=.05$. These administrative employees found out that this concern was being practiced.

Organization. This second profile of the performance management system in the area of organization shows the following result: Administrative managers rated this concern with a mean of 2.34 meaning slightly adequate interpreted as weakness with a t-value of -6.8 and $p$-value of 0.093 and not significant at $\alpha=.05$. The administrative managers saw that this profile was not being practiced.

Table 6. Overall summary-performance management system

\begin{tabular}{|c|c|c|c|c|c|c|c|c|c|}
\hline & & \multicolumn{4}{|c|}{ Administrative Managers } & \multicolumn{4}{|c|}{ Administrative Employees } \\
\hline & & \multicolumn{8}{|c|}{ Test Value: 3.5} \\
\hline & & $\mathrm{Mn}$ & t-val & p-val & Remarks & $\mathrm{Mn}$ & t-val & p-val & Remarks \\
\hline 1 & Vision/Mission/Value/Strategy & 1.97 & -110.4 & 0.006 & Practiced & 1.8 & 27.33 & 0.023 & Practiced \\
\hline 2 & Organization & 2.34 & -6.8 & 0.093 & $\begin{array}{c}\text { Not } \\
\text { Practiced }\end{array}$ & 2.06 & 21.57 & 0.029 & Practiced \\
\hline 3 & $\begin{array}{l}\text { Employees' Talent Management and Leadership } \\
\text { Development }\end{array}$ & 2.39 & -6.84 & 0.092 & $\begin{array}{c}\text { Not } \\
\text { Practiced }\end{array}$ & 2.38 & 6.6 & 0.096 & $\begin{array}{c}\text { Not } \\
\text { Practiced }\end{array}$ \\
\hline 4 & Employee Relations & 1.94 & -43.57 & 0.015 & Practiced & 2.42 & 5.32 & 0.118 & $\begin{array}{c}\text { Not } \\
\text { Practiced }\end{array}$ \\
\hline 5 & Staffing & 1.98 & -77 & 0.008 & Practiced & 1.98 & 51.67 & 0.012 & Practiced \\
\hline 6 & Education, Learning, and Development & 1.78 & -20.5 & 0.031 & Practiced & 1.59 & 51.67 & 0.012 & Practiced \\
\hline 7 & Performance Management & 1.65 & -11.76 & 0.054 & $\begin{array}{c}\text { Not } \\
\text { Practiced }\end{array}$ & 1.65 & 10.58 & 0.06 & $\begin{array}{c}\text { Not } \\
\text { Practiced }\end{array}$ \\
\hline & Grand Mean & 2.00 & -6.84 & 0.092 & $\begin{array}{c}\text { Not } \\
\text { Practiced }\end{array}$ & 1.98 & 6.6 & 0.096 & $\begin{array}{c}\text { Not } \\
\text { Practiced }\end{array}$ \\
\hline
\end{tabular}

The administrative employees rated the mean at 2.06 meaning slightly adequate interpreted as weakness with a $\mathrm{t}$-value of -21.57 and $\mathrm{p}$-value of 0.029 .

It is significant at $\alpha=.05$. These administrative employees found out that this concern was being practiced.

Employee's Talent Management and Leadership Development. This third profile of the performance management system in the area of employee's talent management and leadership development shows the following result: Administrative managers rated this concern with a mean of 2.39 meaning slightly adequate interpreted as weakness with a $t$-value of -6.84 and $p$-value of 0.092 and not significant at $\alpha=.05$. The administrative managers saw that this profile was not being practiced.

The administrative employees rated the mean at 2.38 meaning slightly adequate interpreted as weakness with a $\mathrm{t}$-value of -6.6 and $\mathrm{p}$-value of 0.096 . It is not significant at $\alpha=.05$. These administrative employees found out that this concern was not being practiced.

Employee Relations. This fourth profile of the performance management system in the area of employee relations shows the following result: Administrative managers rated this concern with a mean of 1.94 meaning slightly adequate interpreted as weakness with a t-value of -43.57 and $p$-value of 0.015 and not significant at $\alpha=.05$. The administrative managers saw that this profile was being practiced. 
The administrative employees rated the mean at 2.42 meaning slightly adequate interpreted as weakness with a $\mathrm{t}$-value of -5.32 and $\mathrm{p}$-value of 0.118 . It is significant at $\alpha=.05$. These administrative employees found out that this concern was not being practiced.

Staffing. This fifth profile of the performance management system in the area of staffing shows the following result: Administrative managers rated this concern with a mean of 1.98 meaning slightly adequate interpreted as weakness with a t-value of -77 and $p$-value of 0.008 and not significant at $\alpha=.05$. The administrative managers saw that this profile was being practiced.

The administrative employees rated the mean at 1.98 meaning slightly adequate interpreted as weakness with a $\mathrm{t}$-value of -51.67 and $\mathrm{p}$-value of 0.012 . It is not significant at $\alpha=.05$. These administrative employees found out that this concern was being practiced.

Continuous Education Program. This sixth profile of the performance management system in the area of education, learning, and development shows the following result: Administrative managers rated this concern with a mean of 1.78 meaning slightly adequate interpreted as weakness with a t-value of -20.5 and p-value of 0.031 and not significant at $\alpha=.05$. The administrative managers saw that this profile was being practiced.

The administrative employees rated the mean at 1.59 meaning slightly adequate interpreted as weakness with a $\mathrm{t}$-value of -51.67 and $\mathrm{p}$-value of 0.012 . It is not significant at $\alpha=.05$. These administrative employees found out that this concern was being practiced.

Performance Management System. This seventh profile of the performance management system in the area of performance management system shows the following result: Administrative managers rated this concern with a mean of 1.65 meaning slightly adequate interpreted as weakness with a t-value of -11.76 and p-value of 0.054 and significant at $\alpha=.05$. The administrative managers saw that this profile was not being practiced.

The administrative employees rated the mean at 1.65 meaning slightly adequate interpreted as weakness with a $\mathrm{t}$-value of -10.58 and $\mathrm{p}$-value of 0.06 . It is significant at $\alpha=.05$. These administrative employees found out that this concern was not being practiced.

Overall Summary of Performance Management System. This overall profile of the performance management system in all areas shows the following result: Administrative managers rated this concern with a mean of 2.00 meaning slightly adequate interpreted as weakness with a t-value of -6.84 and p-value of 0.092 and significant at $\alpha$ $=.05$. The administrative managers saw that this profile was not being practiced.

The administrative employees rated the mean at 1.98 meaning slightly adequate interpreted as weakness with a $\mathrm{t}$-value of -6.6 and $p$-value of 0.096 . It is significant at $\alpha=.05$. These administrative employees found out that this concern was not being practiced.

\section{Extent of Correlation of Respondents' Reponses}

Table 7 shows the correlations on respondents' responses in the overall performance management system in each given area such as follows:

Vision/Mission/Value/Strategy. In this area, the administrative managers rated its mean at 1.97 which is slightly adequate and interpreted as a weakness. The correlation was rated at 0.994 with a significant value of 0.000 at a level of significance at $0.01,2$ tailed. It means that the responses by the respondents did not differ significantly and they have the common thoughts about the higher education institutions vision/mission/value/strategy as applied and practiced to their performance management system. On the other hand, the administrative employees rated its mean at 1.80 which is slightly adequate and interpreted as weakness. The correlation was rated at 0.994 with a significant value of 0.000 at a level of significance at $0.01,2$ tailed. The result is the same as the administrative manager in which it did not differ significantly and they have the common thoughts about the higher education institutions vision/mission/value/strategy as applied and practiced to their performance management system.

Organization. In the area of organization, the administrative managers rated its mean at 2.34 which is again slightly adequate and interpreted as a weakness. The correlation was rated at 0.8394 with a significant value of 0.037 at a level of significance at $0.05,2$ tailed.

It means that the responses by the respondents did not differ significantly and they are on the same line of thoughts about the higher education institutions' application and practice in the area of organizing their performance management system. On the other hand, the administrative employees rated its mean at 2.06 which is slightly adequate and interpreted as weakness. The correlation was rated at 0.889 with a significant value of 0.018 at a level of significance at $0.05,2$ tailed. The result is the same as the administrative managers in which it did not differ significantly as to the application of organization to their performance management system. 
Table 7. Overall summary-correlations on respondents' responses

\begin{tabular}{|c|c|c|c|c|c|c|c|c|c|}
\hline & & \multicolumn{4}{|c|}{ Adm. Managers } & \multicolumn{4}{|c|}{ Adm. Employees } \\
\hline & & Mean & Correlation & Significance & LOS & $\mathrm{Mn}$ & Correlation & Significance & LOS \\
\hline & & & & & 2-tailed & & & & 2-tailed \\
\hline \multirow[t]{2}{*}{1} & Vision/Mission/ & 1.97 & 0.994 & 0.000 & 0.01 & 1.80 & 0.994 & 0.000 & 0.01 \\
\hline & Value and Strategy & & & & & & & & \\
\hline 2 & Organization & 2.34 & 0.839 & 0.037 & 0.05 & 2.06 & 0.889 & 0.018 & 0.05 \\
\hline 3 & Employee's Talent & 2.39 & 0.956 & 0.003 & 0.05 & 2.38 & 0.972 & 0.001 & 0.01 \\
\hline \multirow[t]{2}{*}{4} & Employee & & & & & & & & \\
\hline & Relations & 1.94 & 0.546 & 0.262 & 0.05 & 2.42 & 0.884 & 0.019 & 0.05 \\
\hline 5 & Staffing & .98 & 0.999 & 0.000 & 0.01 & 1.98 & 0.999 & 0.000 & 0.01 \\
\hline 6 & Education & 1.78 & 0.998 & 0.000 & 0.01 & 1.59 & 0.975 & 0.001 & 0.01 \\
\hline \multirow[t]{2}{*}{7} & Performance & & & & & & & & \\
\hline & Management & 1.65 & 0.948 & 0.004 & 0.01 & 1.65 & 0.948 & 0.004 & 0.01 \\
\hline 8 & Overall & 2.01 & 0.896 & 0.003 & 0.01 & 1.98 & 0.933 & 0.001 & 0.01 \\
\hline
\end{tabular}

Employee's Talent. The administrative managers rated its mean at 2.39 which is again slightly adequate and interpreted as a weakness. The correlation was rated at 0.956 with a significant value of 0.003 at a level of significance at

$0.05,2$ tailed. It means that the responses by the respondents did not differ significantly and they are on the same line of thoughts about the higher education institutions' application and practice in the area of employee's talent for their performance management system. Accordingly, the administrative employees rated its mean at 2.38 which is slightly adequate and interpreted as a weakness. The correlation was rated at 0.972 with a significant value of 0.001 at a level of significance at $0.01,2$ tailed. The result did not differ significantly as to the application of the employee's talent to their performance management system.

Employee Relations. The administrative managers rated its mean at 1.94 which is again slightly adequate and interpreted as a weakness. The correlation was rated at 0.546 with a significant value of 0.262 at a level of significance at $0.05,2$ tailed. It means that the responses by the respondents did not differ significantly and they are on the same line of thoughts about the higher education institutions' application and practice in the area of employee relations for their performance management system. Accordingly, the administrative employees rated its mean at 2.42 which is slightly adequate and interpreted as a weakness. The correlation was rated at 0.884 with a significant value of 0.019 at a level of significance at $0.05,2$ tailed. The result did not differ significantly as to the application of the employee relations to their performance management system.

Staffing. The administrative managers and administrative employees rated its respective mean at 1.98 which is again slightly adequate and interpreted as a weakness. Its respective correlation was rated at 0.999 with a significant value of 0.000 at a level of significance at $0.01,2$ tailed. It means that the responses by the respondents did not differ significantly and they are on the same line of thoughts about the higher education institutions' application and practice in the area of staffing for their performance management system.

Education. The administrative managers rated the mean at 1.78 which is again slightly adequate and interpreted as a weakness. Its respective correlation was rated at 0.999 with a significant value of 0.000 at a level of significance at $0.01,2$ tailed. It means that the responses by the respondents did not differ significantly and they are on the same line of thoughts about the higher education institutions' application and practice in the area of continuous education and learning for their performance management system. In the same vein, the administrative employees rated its mean at 1.59 which is slightly adequate and interpreted as a weakness. The correlation was rated at 0.975 with a significant value of 0.001 at a level of significance at $0.01,2$ tailed. The result did not differ significantly as to the application of the continuous education and learning for their performance management system.

Performance Management. The administrative managers and the administrative employees rated the mean both at 1.65 which is again slightly adequate and interpreted as a weakness. Its respective correlation was rated at 0.948 with a significant value of 0.004 at a level of significance at $0.01,2$ tailed. It means that the responses by the respondents did not differ significantly and application of the performance management system has not been seriously considered as you will see.

Overall Summary. The administrative managers and the administrative employees rated the mean slightly different from each other with the former at 2.01 and the latter at 1.98 which is slightly adequate and interpreted as a 
weakness. Its respective correlation was rated at 0.896 and 0.933 with a significant value of 0.003 and 0.001 at a level of significance at $0.01,2$ tailed respectively It means that the responses by the respondents did not differ significantly and application of the performance management system has not been seriously considered as you will see.

\subsection{Strategic PMS Is Applicable to the Selected Higher Education Institutions}

The strategic performance management system that is applicable to the five selected higher education institutions as perceived by both the respondents, e.g., administrative managers and administrative employees.

Vision/Mission/Value/Strategy. This has to be enhanced in terms of its philosophy and purpose, be clearly understood by all the players, each sub-units philosophy and purpose should be in line with the general philosophy and purpose of the university, preserve the university's distinction and unique value for the outsiders to get their respect, and a strict implementation of university's policies and procedures.

Organization and Structure. Enhancement of this area depends on the top management's strategy since it involves the university's structure at par with the international higher education institutions; that there is a need in a clear definition and delineation of functional relationships among departments; there is also a need in the review of all job descriptions for the purpose of giving all the employees the right job positions they are assigned and the just compensation;

\section{Summary}

In the areas of organization and structure, the mean was slightly adequate which signifies as a weakness, but practiced by the higher education institutions as perceived by both respondents.

In the areas of employees' talent management and leadership development, the mean was slightly adequate which signifies as weakness, and practiced by the higher education institutions as perceived by the administration managers. The administration employees perceive it as a weakness and not practiced by the higher education institutions.

In the area of employee relations, the mean was slightly adequate which signifies as a weakness, and practiced by the higher education institutions as perceived by the administration managers. The administration employees perceives it as a weakness but not practiced by the higher education institutions. In the area of staffing, the mean was slightly adequate which signifies as a weakness, but practiced by the higher education institutions as perceived by both the respondents. In the area of continuous education program, the mean was slightly adequate which signifies as a weakness, but practiced by the higher education institutions as perceived by both the respondents. In the areas of performance management, the mean was slightly adequate which signifies as a weakness, but not practiced by the higher education institutions as perceived by both respondents. In all the areas, the mean was slightly adequate which signifies as a weakness, but not practiced by the higher education institutions as perceived by both respondents. In the profile of vision/mission/value/strategy the correlation did not differ significantly and they have the common thoughts about the higher education institutions vision/mission/value/strategy as applied and practiced to their performance management system. In the organization and structure profile, the correlation did not differ significantly as to the application of organization to their performance management system.

For the employees' talent management and leadership development the correlation did not differ significantly as to the application of the employee's talent to their performance management system.

For continuous education program the correlation result did not differ significantly as to the application of the continuous education and learning for their performance management system. For performance management system the correlation result did not differ significantly and application of the performance management system has not been seriously considered by the top management. Overall, the administrative managers and the administrative employee's correlation results did not differ significantly and application of the performance management system has not been seriously considered as you will see. For the PMS strengths and weaknesses, the respondents' perceptions show that there is no evidence of strengths based on the gathered data but all weaknesses in accordance with the minimum rating scales of 3.5 to 5.0 for strength and 1.0 to 3.49 as weakness. In the areas of vision/mission/value/strategy, these was rated by both the respondents as weak but practiced.

In the areas of organization and structure, the administrative managers rated this area as weak and not practiced while the administrative employees perceive that the practice of the organizational elements was not that effective and needs some enhancement to fulfill the objective of the PMS. For performance management this area was perceived as weak and not practiced.

The researcher suggested for the enhancement of all the profiles presented in this study such as: 
Vision/Mission/Value/Strategy. This has to be enhanced in terms of its philosophy and purpose, be clearly understood by all the players, each sub-units philosophy and purpose should be in line with the general philosophy and purpose of the university, preserve the university's distinction and unique value for the outsiders to get their respect, and a strict implementation of university's policies and procedures.

Employee's Talent Management and Leadership Development. All employees should be given the chance in exhibiting their talents and leadership by letting them actively participating in the review, development and implementation of the PMS; enhancement of their management skills and their work ethics and other strong qualifications; developing their leadership traits creatively and innovatively in their decision-making activities; defining a meaningful career path and succession; carrying on the performance development plans for potential leaders with the support of top management.

Continuous Education Program. The area needs enhancement in terms of training policies, schedules and budget; training cost indicators; training man-hours for purposes of balanced budget; the use of training programs and review the contents of the programs periodically.

Performance Management. This program itself is a tool in which there is a need to conduct a periodic surveys on employee satisfaction or performance assessment cycle by using established criteria; the use the key performance indicators (KPI) in all functions, positions and other criteria that will enhance the system; a need to coach, mentor, and counsel as part of performance assessment mechanism in enhancing the employee's job performance; and conduct performance development plan, behavioral appraisal, and employee feedbacks to develop employee potentials; a need to involve everyone in the performance assessment like the employee, immediate superior, department head, and the staff.

\section{References}

Armstrong, M. (2006). A Handbook of Management Techniques Revised (3rd ed.). Bell \& Bain, Glasgow, Great Britain.

Armstrong, M. (2006). Human Resource Management Practice (10th ed.). Kogan Page Limited, UK.

Badiru, A. B., \& Pulat, P. S. (2000). Comprehensive Project Management. Prentice Hall, Inc., New Jersey.

Bateman, T. S., \& Snell, S. A. (2004). Management the New Competitive Landscape. McGraw Hill, New York.

Borromeo, R. T. (1995). Strategies for Effective School Management. Phoenix Publishing House, Inc., Quezon City, Philippines.

Carroll, M. (1986). MBO as a Management System Designed to Achieve Organizational Effectiveness. Civil Service Regulation No. 410 of 1981 (Appendix 3).

Clawson, J., \& Haskins, M. E. (2006). United Kingdom: Cambridge University Press.

David, F. R. (2007). An Introduction to Strategic Management. Prentice South Asia Pte Ltd., Singapore.

Decenzo, D. A., \& Robbins, S. P. (2007). Fundamentals of Human Resources Management (9th ed.). John Wiley \& Sons, Inc., USA Dressler, Gary (2009).

Dressler, G. (2004). A Framework for Human Resource Management (3rd ed.). Pearson Education, India.

Furumoto, M. (2004). Master's Thesis the Effect of Using Impression Management on the Performance Rating of Affirmative Action Beneficiaries.

Goodworth, C. T. (1985). Effective Delegation. Brookfield Publishing Inc., Vermont, USA.

Hitt, M. A., Ireland, D. R., \& Hoskisson, E. (1999). Strategic Management Competitiveness and Globalization (3rd ed.). South-Western College Publishing, Cincinnati, Ohio.

Hoffman, S. (1995). Research on Job Performance in Making Administrative or Personnel Decisions such as Compensation, Promotions, Discipline, Terminations or Layoffs.

Jones, Pam (1999). Performance Management Pocketbook. Management Pocketbook Limited, U.K.

Juran, J., \& Godfrey, A. B. (2000). Juran's Quality Handbook (5th ed.). McGraw-Hill International, Singapore.

Kermally, S. (1999). The Management Tool Kit. Thurgood Limited, London, UK.

Keuning, D. (1998). Management A Contemporary Approach. London: Pitman Publishing.

Kikoski, S. (1999). Master's Research Study on Effective Communication in the Performance Appraisal.

Mello, J. A. (2006). Strategic Human Resource Management (2nd ed.). Thompson, South-Western, United 
States.

Milkovich, B., \& Newman, K. (2005). Performance Appraisal Techniques.

Po-Doai. (1998). Comparative Study of Personnel Management of Thai and Foreign Commercial Banks in Bangkok.

Quinn, R. E., Faerman, S. R., Thompson, M. P., \& McGratch, M. R. (1996). Becoming a Master Manager (2nd ed.). John Wiley and Sons, Inc., Canada.

Robbins, S., \& Coulter, M. (2008). Management (9th ed.). Prentice-Hall of India Private Limited, New Delhi.

Thompson, A., Strickland, A., \& Gamble, J. (2005). Crafting and Executing Strategy the Quest for Competitive Advantage. New York: McGraw Hill/Irwin.

\section{Copyrights}

Copyright for this article is retained by the author(s), with first publication rights granted to the journal.

This is an open-access article distributed under the terms and conditions of the Creative Commons Attribution license (http://creativecommons.org/licenses/by/3.0/). 